\title{
The perception of tourism in coffee-producing equatorial countries: an empirical analysis
}

\author{
CECILIA CASALEGNO*, ELENA CANDELO*, GABRIELE SANTORO*, PHILIP KITCHEN** \\ *UNIVERSITY OF TURIN, ITALY \\ **SALFORD UNIVERSITY BUSINESS SCHOOL, UK AND ICN NANCY, FRANCE
}

\begin{abstract}
The literature has emphasized the importance of food tourism in mature and some emergent economies for growing consumption related products (for example, wine, beer, rice and tea), and attempts have also been made to study tourism levers and threats in developing economies. However, to our knowledge, little research has been conducted about the potentially of developing tourism activities around coffee producers and its farms, located in equatorial countries, to see if a coffee tourism market is developing and if this could enhance the positive value of the coffee lands brand image perception. Thus, this paper explores the antecedents of perceptions, potentialities, attitudes and behavior of tourists, particularly with regard to coffee tourism and coffee cultivation visits. To reach the paper's goal, the study employs a quantitative method through a survey approach involving a sample of potential tourists. The study findings indicate that while the effect of gender and age on coffee cultivation visit perception is not significant, coffee consumption and travels in coffee-producing countries have a positive and significant effect. The findings help to draw some relevant theoretical and managerial implications.
\end{abstract}

\section{Keywords}

coffee tourism, coffee agriculture, developing equatorial countries, destination branding, tourists' perceptions, experience economy, stakeholder theory.

\section{Acknowledgement}

This paper was first presented at the 2019 INEKA Annual Conference in Verona, Italy. We thank the anonymous reviewers and Editor for their comments which have strengthened the paper greatly.

\section{Introduction}

During the last two decades, many articles have been published with the aim of linking food events and festivals to sustainable and powerful tourism (Lee and Acordia, 2011). These events have a proven positive effect on local communities and their livelihood (Mason and Paggiaro, 2009; Zhou, 2014; Chen et al., 2016). Furthermore, they impart a particular image to a destination, where the aim is to differentiate the destination itself from metropolitan places (Lee and Acordia, 2011). This aim is 
contextualized in Anholt's (2003) destination branding theory, according to which tourism, interacting with export, attracts investments, cultural elements, and local people, forming a virtuous circle. These factors act synergistically to reinforce each other and thus enhance the value of the place brand and its image (Aaker, 1996; Kapferer, 1997; Anholt, 2003; Chang and Chieng, 2006). Recent literature has highlighted that consumers, in most cases, want not only a holiday per se but also the cultural experience of the places visited (Byrd, 2017; Gibbs and Holloway, 2017; Spielmann et al., 2018). According to Oh et al. (2007), tourism is the "forefront of staging experience" (p.119). An active experience (Bruyere et al., 2009) of a place impacts, by leveraging on tourists' perceptions, the positive image of the destination (Beerli and Martin, 2004; Kivela and Crotts, 2006; Cheng et al., 2012; Tapachai and Waryszan, 2000). Literature indicates that active participatory tourism can and does affect and enhance destination performance (Byrd, 2017), through a system in which local players, communities, and consumers can co-create value (Freeman, 1984), with joint interests and "congruency between perspectives" (Freeman et al., 2010; p. 150).

Scholars consider the importance of food in tourism, because it is perceived as a way to experience a place (Spielmann et al., 2018) and a modality that connects tourists and local culture (Sims, 2009), rituals (Joliffe, 2003; Plummer et al., 2005; Joliffe, 2010) and heritage (Zhou, 2014), reflecting the above-mentioned 'congruency between perspectives' (Byrd, 2017). Thus, food production can play a beneficial role in turning a tourist from being passive to active (Leonidou et al., 2015).

Many articles have emphasized the importance of food tourism in mature and emerging countries for growing consumption products (for example, wine, beer, rice and tea), and some attempts have been made to study tourism levers and threats in developing countries (see for example: Torres, 2003; Lacher et al., 2010; Anbalagan and Lovelock, 2014; Bresciani et al., 2016).

However, following an extensive literature search process, even though there has been a worldwide increase of $2.1 \%$ in coffee consumption in 2018 compared to that in 2017 , there is little information about the possibility to develop tourism activities around coffee-producing regions or how a coffee tourism market could enhance the brand image perception of these regions. To address this gap in the literature, we employed a quantitative methodology involving a survey approach. Accordingly, we explored the antecedents of perceptions, potentiality, attitudes and behavior of tourists, particularly with regard to coffee tourism and coffee cultivation visits. In this context, coffee cultivation visit perception refers to the extent to which consumers perceive coffee-producing places and countries. Data were collected using an online platform and processed through ordinary least squares (OLS) regression analysis. Respondents were tourists and potential tourists from around the world.

The research provides several implications. First, it suggests that demand and awareness of coffee production and consumption increase the willingness of tourists to know more about coffee history, thus transforming coffee demand into a whole new experience that goes beyond the sole consumption of 
coffee. Second, this research confirms and augments the links between food, tourism, and destination image in the specific context of coffee. Thus, this research indicates that coffee consumption and travels can boost awareness toward coffee cultivation visit perception and an overall coffee tourism experience, thus creating shared value for stakeholders and the coffee industry.

The remainder of the paper is organized as follows. The next section reviews the literature regarding touristic destinations, food, and rural tourism in both mature and developing equatorial countries, coffee-producing countries, with their contemporary opportunities and challenges. Then, we present data, methodology, and variables used in our empirical study. Finally, we highlight the results of the analysis and propose a novel discussion in the light of existing literature as well as recommendations to practitioners.

\section{The touristic destination: from the experience economy to the stakeholder theory}

Destination branding is developing as a significant new area of tourist interest, and for this reason, Beerli and Martin (2004) state that this needs to be 'managed with a precise strategy to meet new needs and wants shaped by new people's characteristics'. In particular, recent literature highlights that consumers, in most cases, want not only a holiday per se but also the cultural experience of the places visited (Gibbs and Holloway, 2017; Spielmann et al, 2018). So, if we speak about service providers' requirements to meet needs and wants, tourists' experience is a part of growing demand in the tourism sector. Indeed, according to Quan and Wang's (2003) interesting conceptual model of the tourist experience, tourism represents one of the most important examples of today's 'experience economy', an area or theory founded in the work of Gilmore and Pine (1998). This theory conceptualizes that experience is distinct from goods and services; it represents a stand-alone demand and, consequently, a way to augment value creation for both customers and service providers. According to the same work (ibid, 1998), 'experience is about ... the customer participation', on the one hand, and what is termed 'environmental responsibility' (p. 101), on the other. Considering this second 'dimension', the authors note a very interesting aspect concerning the concept of 'experience': i.e. the import attached to 'where' customers consume the experience itself, by absorbing the external elements and by engaging all five human senses. Later, the literature (Quan and Wang, 2003; Oh et al., 2007, Coudounaris and Sthapit, 2017, Spielmann et al., 2018) also links this aspect to the tourism sector, as it is the 'forefront of staging experience' (Oh et al., 2007: p. 119). Everything in tourism is related to the experience: what consumers see, what they feel, the moments they enjoy and what they learn (Oh et al., 2007). Furthermore, it concerns various aspects of tourism; the experience can begin before the trip, continue during the trip, and does not end after the travel, for, its memory will endure (Tapachai and Waryszak, 2000). Most importantly, active participatory tourism can and does affect and enhance destination performance; in other words, a type of place where local players, communities and consumers can co-create value, which is the base of Freeman's (1984) stakeholder theory. By extension, to be successful, tourism must call 
into action the stakeholder participation, which is one of the renowned bases of the concept of sustainability (Byrd, 2017; Spielmann et al., 2018; Franceschelli et al., 2019).

The knowledge of a place we refer to has to be explained, as the main touristic destination characteristic is that the experience of it begins before departure (Tapachai and Waryszak, 2000). It is a sort of indirect experience, which evidences destination consumption values, formed with the aim of information gathered through websites, blogs, tour operators and via trusted word-ofmouth from people's previous experiences of that destination. All gathered information allow potential consumers to create a mental representation of the chosen destination, and this plays a key role in the touristic place selection and choice. Thus, tourists are now more facilitated in finding information than in the early 1990's, when Um and Crompton (1992) argued about the scarcity of knowledge regarding a certain territory prior to visiting (Tapachai and Waryszak, 2000). Knowledge is, however, still an important driver in the current tourism industry: the more people know about a place, the more they can develop the desire to visit it in order to have an experience of an already indirectly known factor, for example types of food, particular services, or a fascinating landscape (Gibbs and Holloway, 2018). These statements augment the importance of the experience economy in the tourism industry (Quan and Wang, 2003; Oh et al., 2007, Coudounaris and Sthapit, 2017; Gibbs and Holloway, 2017; Spielmann et al., 2018).

The above becomes more interesting when we think that the personality of a tourist can affect the typology of trip he/she decides to undertake (Oh et al., 2007) and that the experience of a place has a direct impact on attitudes and beliefs a tourist has towards a certain kind of destination (Pine and Gilmore 1999; Gilmore and Pine 2002a, 2002b). This experience directly acts on the filters people use to interpret the reality (Oh et al., 2007), and has a strong impact on their further decisions. Of course, the more positive the experience of a place, the more the consumer perception of that place will have good memories_and, consequently, lead to an enhanced value of that destination.

The experience of a destination has_directly impacts upon image creation (Beerli and Martin, 2004), and scholars have always sustained that the image of a certain brand is a fundamental part of brand value creation (Aaker, 1996; Kapferer, 1997; Anholt, 2003; Chang and Chieng, 2006). On the other side, to activate the mechanism of image creation, it is necessary to work on items that will enable to create an experience regarding the personality of a brand (Kotler et al., 2017). This is because the destination image is defined as a mental representation of a knowledge (Baloglu and McCleary, 1999) of a place, good, service, or, as stated by Crompton (1979), a set of beliefs and perceptions tourists have of a certain location and which may have evolved during the years from something considered organic (Fakeye and Crompton, 1991) to a more complex issue. This aspect has been considered by Hosany et al. (2006) who analyzed the cognitive and affective sides of the concept 
of destination image and demonstrated that 'destination image and destination personality are related concepts' (p. 641). More precisely, the image is more related to the affective dimension of the image creation process. Indeed, the brand personality is relevant in destination branding mainly for three reasons, namely sincerity, excitement and conviviality, as defined by the authors (Hosany et al., 2006). Of course, even the strongest destination personality is not a guarantee of success (Hultman et al., 2017), as the formation of a positive image in consumers' mind is a combination of the above-mentioned issues and the intrinsic motivations which lead a person to experience a place (for example in Balogou and McClerry, 1999, to Hultman et al., 2017).

In recent times, a strong motivation, the so-called 'green tourism', is highlighted by academics and practitioners. This refers to the experience of place authenticity, without modifying it. Leonidou et al. (2015) base their hypothesis on what they call 'green tourism' on the fact that people interested in this kind of tourism are generally more engaged in outdoor activities, in environmental issues and in organizations which respect nature. Furthermore, their concerns about local environmental problems are affected not only by the experience they have of a particular place but also by the background they already have of the issues they want to experience, which_directly impact upon attitudes (Leonidou et al., 2015).

Thus, the experience is a need, and it is affected by a trend: consumers want to go beyond the will to know and to see certificated the effort a firm or an organization of interest puts on environmental and social aspects; it is the co-creation of a process through which a certain kind of value is generated, and this refers to Freeman's $(1984,2010)$ stakeholder theory, according to which the interests of various stakeholders' groups 'are joint' (Freeman, 2010: p. 9). An environmentally sustainable approach is defined as a stakeholder theory common application in the marketing literature (Freeman et al., 2010: p. 158) and sustainability, seen and approached in this way, is, according to academics and practitioners - the new stakeholders' demand in recent years (Franceschelli et al., 2018; Santoro et al., 2018). As mentioned in literature (Byrd, 2017), sustainability has become an important topic with regard to tourism planning and development. In particular, if we consider the concept of citizenship and the integration with a territory, it is understandable that sustainable effects help, generally speaking, the organization in effectively communicating with their stakeholders(see Nishant, Goh and Kitchen, 2016), consumers in particular; moreover, good results are derived from the evidence of sustainable performances, as sustainable performances (already considered by Collins et al. in 2007 'sustainable corporate performances') represent a strong customer's beliefs, attitudes (Collins et al., 2007) and judgement (Civera et al., 2018) affecting element (Kitchen, 2019). We are witnessing a shift, in many cases, to a more sustainable consumption that has been well defined by Phipps et al. (2013), as the kind of 'consumption that simultaneously optimizes the environmental, social, and economic consequences of acquisition, use, and disposition in order to meet 
the needs of both current and future generations' (p. 1227). This actually refers to the concept of increasing stakeholders' importance in the value creation process (Freeman, 1984; Donaldson and Preston, 1995; Freeman et al., 2010), which, of course, is not new, but has been gaining momentum in recent years, as the above-mentioned literature confirms that 'congruency between perspectives' leads to an increase in stakeholders' likelihood to cooperate in service delivery (Freeman et al., 2010: p 150).

The literature also suggests that food consumption is an important driver for the experience (Richards, 2002; Kivela and Crotts, 2006). According to Oosteveer (2006) and Mak et al. (2012), food consumption in the general context is recognized as a collection of contextual and evolving social practices, where food no longer merely serves as sustenance, but it is also a way to relate to other people in social, cultural, and political terms. Indeed, food consumption can be connected to the concept of experience, and its symbolic meaning has gained importance in the tourism sector.

\section{Food, people's perceptions, and rural tourism}

Food is seen as 'the extension of the ontological comfort of home' (Quan and Wang, 2003, p 301), and is viewed as a key element to enhance the development and attractive potential of a certain territory (Hall et al., 2010). Moreover, this is not necessarily new: as much earlier

Greenwood (1972) had noted the important of the connections

between tourism development_and the accompanying stimulation of

commercialization of agricultural products. However, he was not alone $\underline{\text { in }}$ considering this nexus, as Hermans (1981), Echtner and Ritchie (1993), Crompton and McKay (1997), and more recently, Quan and Wang (2003), Hall and Sharple (2003), Hall et al. (2003) and Dougherty and Green (2011), among the others, have also done the same. This confirms that links between food and rural tourism is valid, even more so if we consider that local gastronomy encourages direct sales of farm produce (Quan and Wang, 2003; Kivela and Crotts, 2006; Cheng et al., 2012). Food is a way that enables experience of place (Spielmann et al., 2018); moreover allows people to connect with local culture (Sims, 2009), rituals (Joliffe, 2003; Plummer et al., 2005; Joliffe, 2010) and heritage (Zhou, 2014); and an issue which touches both the cognitive and affective aspects of the destination image (Baloglu and McCleary, 1999). Thus, food has a beneficial role in turning a tourist from being passive to being active (Bruyere et al., 2009; Leonidou et al., 2015), and this has a strong impact on the brand image of a territory (Tapachai and Waryszan, 2000; Kivela and Crotts, 2006; Cheng et al., 2012), considering that it works on the concept of authenticity (Midtgard, 2003; Plummer et al., 2005; Zhou, 2014; Coudonaris and Sthapit, 2017; Spielmann et al., 2018), as it brings tourists and local people closer. 
The effect of linking food and tourism finds its relevance not only in the context of the experience economy (Byrd, 2017, Spielmann et al., 2018), but it is fundamental to highlight that the value created by tourists in food and beverage stimulates and creates local labor with an impact on the economic and social situation of the inhabitants (Kim et al., 2009). Consequently, the link between agriculture and tourism can be seen as a mean for improving local development and social inclusion (Echtner and Ritchie, 1993; Torres and Momsen, 2004; Meyer, 2007; Torres and Momsen, 2011). Indeed, agriculture can be considered as 'a legacy from local people traditions and activities' (Rogerso, 2012); it contributes to reinforce a process of cultural identity and to boost local territories and communities (Donert and Light, 1996; Jansen-Verbeke, 2009). Furthermore, this can create new opportunities to protect and maintain core elements of a certain territory for which some social and economic conditions (Candelo et al., 2018; Civera et al., 2019), together with climate change, represents a challenge and a threat (Sun et al., 2011). Again, it becomes clear that it is possible to link the benefit of rural tourism to stakeholder theory elements which consider the efforts of creating common benefit (Byrd, 2017).

It is possible to highlight this trend by considering wine, beer and tea industries; these are contexts in which the development of raw material consumption, after a certain kind of transformation, has drawn the attention of consumers to their higher-level supply chain, thus augmenting rural and agricultural tourism (Plummer et al., 2005; Sims, 2009; Quadri-Felitti and Fiore, 2012; Sidali et al., 2013; Cheng et al., 2016; Byrd, 2017).

In developed countries, the link between particular agriculture outputs (food) and the tourist's attraction potential has been already investigated and proven (Hall et al., 2003; Torres, 2003; Hall and Sharple, 2004; Plummer et al., 2005; Lacher et al., 2010). For example, Mason and Paggiaro (2009) analyzed how food and wine events can contribute to the enhancement of the image of the Friuli Venezia Giulia Region in Italy. Zhou (2014) evaluated the importance of tea events in China for attracting tourists, and his results confirmed that this kind of tourism has a certain impact on local value creation. The same finding has been proven by Chen et al. (2016), and they add to the above-mentioned theory that governments themselves have interest in developing food events in order to augment local tourism. This is an evidence of the above-mentioned theory according to which the experience coming from the consumption of a local food increases authenticity and helps define place image (Spielmann et al., 2018).

The link between tourism and food becomes more interesting when we consider that the literature has also demonstrated, during the recent years, tourism has risen even in places where food grows because tourists want to discover what is behind the finished products they consume (Quadri-Felitti and Fiore, 2012). This is an interesting trend to highlight, as it could help some areas despite the still-felt negative 
effect caused by the 2008 financial crisis; Quadri-Felitti and Fiore (2012) stated that in those years, wine consumption was increasing, despite the drop in sales during the worldwide global recession. Analysis of the wine industry is peculiar and demonstrates that higher consumption directly impacts increased interest in rural tourism interest (Hall et al., 2003). A decade later, Chen et al. (2016) analyzed tourism around rice terraces in Japan and, once again, the result was the observation of the co-evolution of nature and people, together with the fact that consumption of a certain food is related to the desire of discovering what lies behind it: this led to a considerable awareness of the higher level of rice supply chain, its rituals and its heritage, and its local farmers who, instead of leaving the agricultural production per se, decide to continue their family tradition. This confirms that tourism is successfully linked to agriculture and can act synergistically together (Torres, 2003; Lacher et al., 2010).

During the last 15 years, beer consumption has also risen (Plummer et al., 2005; Alonso, 2011), and from the studies of all the authors, it is possible to find evidence of the above-mentioned trend even in this market: the increase in beer consumption is related to brewery curiosity by beer consumers. Furthermore, Plummer et al. (2005) added that even in this case, tourists are seeking authentic and unique experience, things that they have the opportunity to find when they get closer to local producers (Alonso, 2011).

Tourism around tea agriculture is probably the oldest (Joliffe, 2003), and literature suggests that rural destinations are using stories, rituals and heritage of this raw material-for example in India and Malaysia - to attract people and to differentiate themselves (Cheng et al., 2012)

Furthermore, the coffee market, considering that we are talking about one of the most consumed commodities around the world (Petchers and Harris, 2008), has been analyzed under the tourism aspect by Chand and Chieng (2006), even though they considered only tourism developed around coffee consumption. In their work, they conclude that the relationship with brand is built on the individual experience and that this experience, which has to be compelling, has a strong impact on the shared experience, which is connected to the 'congruency between perspectives' that characterizes the stakeholder theory (Freeman, 2010: p. 150).

Despite the_preceding review, to our knowledge, there is still a gap in literature about the coffee market and potential tourism and how this could be seen in terms of cooperation between various stakeholder_actions and their joint interests. This led to the first research question: 
RQ1: Are coffee places and countries interesting as tourism destinations, for the territorial value cocreation?

\section{Rural tourism in equatorial countries: facing threats with new opportunities}

The relationship between agriculture and tourism has been researched in mature economies (Hermans, 1981; Dougherty and Green, 2011), while in developing economies, it is viewed as complex to say the least (Torres and Momsen, 2011) because of socio-economic conditions and population behavior. Thus, studies on agriculture-tourism linkages in developing countries are more recent. That said, according to Meyer (2007), local agricultural products, traditions and rituals are among key benefits an indigenous tourism industry can offer in the developing world.

Even though communities in developing countries have considered tourism facilities as a step further than agriculture, in the belief that this could deplete resources from the countries (Torres and Momsen, 2011), some factors deserve attention.

From the present coffee farmers' point of view, local communities in developing countries are helped by NGOs and coffee roasters to augment their social inclusion and sense of entrepreneurship - at least in the farming sector (Civera et al., 2019). Thus, some communities have reached a fairly good level of awareness on how to improve income in new ways, even though, for some coffee farmers' communities, the migration of youth from productive country areas still represents a threat (Candelo et al, 2018).

Despite this hindrance, Torres (2003) and, years later, Lacher et al. (2010) sustain that the service sector could be linked with agriculture with some benefits which have an impact on the destination image (Tapachai and Waryszak, 2000) and on the local community's social wellness and inclusion (Joliffe, 2010).

Rural and agricultural tourism, however, still find some difficulties when this concept is to be applied to developing or emerging countries, places in which political turmoil and economic aspects have always affected possible tourists' perceptions (Anbalagan and Lovelock, 2014). Furthermore, populations in developing countries have always viewed tourism through resources could be taken away from agricultural activities (Joliffe, 2010).

Despite the above-mentioned conditions, in the last few years, many authors have striven to demonstrate that a certain kind of sustainable tourism could represent an important mean of country development (Berlin and Martin, 2004; Torres and Momsen, 2004; Meyer, 2007; Vorley and Proctor, 2008; Joliffe, 
2010), thus representing a 'comparative advantage in development terms' (Jenkins, 2015) that is more effective than in traditional industries (for instance, general agriculture or mining).

If literature supports the above-mentioned theory, to our knowledge, there is little information on how coffee consumption, which is increasing at a dramatic rate worldwide and which consists of a long and complex supply chain (Candelo et al., 2018), can affect the tourism of those territories in which coffee grows (Joliffe, 2010), namely the equatorial areas — an issue which leads, most often, to social, economic, structural, and political problems. Coffee lands are interesting fields of research because they well represent a common situation shared by those countries who are facing risks and opportunities coming from having the chance to produce important raw materials and the possibility to offer a peculiar experience without having sufficient resources to develop it without problems (Beerli and Martin, 2004).

As already stated, we are witnessing a growth in coffee consumption worldwide, which, together with democratization of the knowledge about roasters, their livelihood and the rituals that can be linked to coffee growth, is definitively affecting the interest of people (Anbalagan and Lovelock, 2014). This interest is also growing because of the positive impact coffee, together with its rituals and traditions, has on its lands' destination branding (Meyer, 2007; Joliffe, 2010; Anbalagan and Lovelock, 2014).

The link between tourism and agriculture can be considered as a part of the cultural, historical, natural and social environment, and atmosphere of a place to build an attractive destination brand image for a developing country (Beerli and Martin, 2004). There are several reasons why local farmers in developing countries should be supplying tourism enterprises with food products (Beerli and Martin, 2004; Torres and Momsen, 2004; Meyer, 2007; Joliffe, 2010), and literature shows that agriculture and tourism linkage can create positive synergies, leading to better social inclusion/integration of smallholder farmers and agricultural producers in an economy (Vorley and Proctor, 2008; Oxfam International, 2010).

Indeed, in accord_with the literature (Rueegg, 2009; Torres and Momsen, 2011), tourism has become a lever of economic development, particularly where there is growing recognition of the potential for creating synergistic relationships between tourism and agriculture. Moreover, growing coffee consumption in the world has accelerated research in coffee-producing countries. It thus presents an interesting research area mainly because coffee-producing countries tend to be still in their economic and social development phase.

\section{Coffee-producing countries: lands of growing opportunities and challenges}


Coffee agriculture involves 25 million people worldwide (Watson and Achinelli, 2008) who base their livelihoods on coffee and often cultivate small land holdings, while facing various daily social, economic and environmental challenges (Joliffe, 2010). This is the reason the enhancement of local tourism is seen as an approach through which it is possible to economically enhance the lives of farmers and their families and to build the local economy in new directions. Actions to facilitate this are tailored often with the help of coffee roasters and NGOs - to the needs of the younger generation, with a goal of creating new service organizations (Civera et al., 2019). This reflects the view of Ritchie and Crouch (2003), which considers that diversification is essential for competitiveness and sustainability. In this regard, establishing tourism activities related to coffee can be an effective diversification strategy to enhance the coffee appeal for tourists and locals in terms of agricultural techniques, culture and heritage (Joliffe, 2010; Anbalagan and Lovelock, 2014), and all these elements have an impact on the destination image (Crompton, 1979, 1991; Aaker, 1996). Involving small producers and the youth in activities related to coffee production means establishing inclusive business models that incorporate the needs of local communities, such as employment, and providing tourists with new images, perceptions, and experiences of the country (Vorley and Proctor, 2008; Brenes et al., 2014; Byrd, 2017; Spielmann et al., 2018). Furthermore, many studies over the years (Britton, 1979; Echtner and Ritchie, 1991; Cohen, 1993; Echtner and Prasad, 2003; Morgan et al., 2011; Anbalagan and Lovelock, 2014) have shown that, firstly, the reputation of a destination is critical and has a strong impact on the will to visit it. Secondly, a negative image can be linked to how a place is perceived as unsafe (Anbalagan and Lovelock, 2014), poor in education (Echtner and Ritchie, 1991), having infrastructural issues (Gauci et al., 2002) and/or politically instable (Grosspietsch, 2006). Some coffee-producing countries have been affected, during the past several years, by these characteristics, and they had to face many difficulties coming from their negative image (Anbalagan and Lovelock, 2014), on the one hand, and by scarcity of resources on the other. Despite the above findings, a few studies developed around coffee-based tourism showed that farmers can take advantage of increasing demand for coffee and its consumption worldwide and that the coffee-related tourism offers an 'enormous value-added potential' (Anbalagan and Lovelock, 2014) in developing a beneficial image which is the output of the still valid five consumptions values reported by Sheth et al. (1991) functional, social, emotional, epistemic and conditional - and already tested by Tapachai and Waryszak in 2000 in comparing two very different_countries

To add evidence to the extant literature about coffee-related tourism, and to differentiate our research from that of Anbalagan and Lovelock, which explored the views of ten coffee industry experts in 2014, a second research question drove composition of the online survey we later administered to test coffee consumers as potential tourists. 
RQ2: Can travels in coffee-producing countries reflect an improved coffee-related tourism and a beneficial destination image?

\section{Methodology}

Data, sample, and variables

We chose a quantitative methodology involving a survey approach to provide an answer to the research questions. Although most of the previous studies on this topic are conceptual or qualitative (Florek \& Conejo, 2007; Toledo \& Moguel, 2012; Anbalagan \& Lovelock, 2014), we chose a survey methodology to explore the extent to which coffee places and countries are appreciated as tourism destinations. Accordingly, we explored the antecedents of coffee cultivation visit perception that could be seen as the extent to which consumers perceive coffee places and countries. This research design is in line with the study of Spielmann et al. (2018), which explored the psychology of consumers in extracting value from consumption experiences. Data were collected using an online platform in line with previous studies (Jiang et al., 2008; Zhang \& Mao, 2008). Before sending the questionnaire, a pre-test in Italy with a random sample of 10 people who agreed to participate was done, to ensure that all questions were clear. Accordingly, some questions were amended as needed.

In total, we received 288 responses from December 2018 to January 2019. Most respondents lived in Italy, while other respondents live in other countries. The questionnaire was written in English. It is reasonable to state that our research is directed towards active tourists, who are increasingly getting better at speaking English fluently and therefore we do not think that the usage of English as language for the questionnaire represented a problem.

In the questionnaire, we asked respondents to provide general personal information such as age, gender, educational background in line with previous studies (Chen et al., 2016). Then, following methodological procedures of Chen et al. (2016) and theoretical insights of Tapachai and Waryszan (2000), we developed several questions regarding coffee cultivation visit perception, coffee consumption, etc. We left an open space at the end of the questionnaire to enable respondents to provide comments that could be useful in understanding their views. The following table shows the variables used in the empirical research. 
Table 1. Questionnaire and questions

\begin{tabular}{|c|c|}
\hline Variable & Description \\
\hline Gender & Male/Female \\
\hline Age & Years from birth \\
\hline Country & Country of birth \\
\hline Coffee consumption & Yes/No \\
\hline No. of coffee & $\begin{array}{l}\text { Number of coffees per week: } \\
0=\text { none } \\
1=\text { less than } 5 \\
2=\text { between } 5 \text { and } 10 \\
3=\text { between } 11 \text { and } 20 \\
4=\text { more than } 20\end{array}$ \\
\hline Coffee consumption motivation & $\begin{array}{l}\text { If you are used to consume coffee, why do you consume it? } \\
\text { - it is a family tradition } \\
\text { - it represents a moment of relaxation } \\
\text { - coffee is useful to remain awake during the day } \\
\text { - it represents a social tradition for me }\end{array}$ \\
\hline No. of visited countries & Number of visited countries from a list of coffee-producing countries \\
\hline Visited country motivation & $\begin{array}{l}\text { If you visited at least one of the above-mentioned countries, with whom } \\
\text { and why did you visit it/them? } \\
\text { - it was a vacation (with my family) } \\
\text { - it was a vacation (by myself) } \\
\text { - it was a vacation (with one or few friends) } \\
\text { - it was a group vacation } \\
\text { - it was a vacation (with my partner) } \\
\text { - it was a working travel because I work in the coffee industry (and I } \\
\text { it was a working travel because I work in the coffee industry (and I } \\
\text { - it was with a colleague) } \\
\text { industry (and I was alone) } \\
\text { it was a working travel because I would like to work in the coffee } \\
\text { industry (and I was with a colleague) }\end{array}$ \\
\hline Coffee cultivation visit & Yes/No \\
\hline Coffee cultivation visit enjoyed & Yes/No \\
\hline $\begin{array}{l}\text { Potential coffee cultivation visit } \\
\text { perception } 1(C C P 1)\end{array}$ & $\begin{array}{l}\text { To me, coffee cultivations would be extremely remarkable and interesting } \\
\text { (1-5 Likert scale) }\end{array}$ \\
\hline $\begin{array}{l}\text { Potential coffee cultivation visit } \\
\text { perception2 }(C C P 2)\end{array}$ & $\begin{array}{l}\text { The coffee history and its traditions are very interesting for me (1-5 Likert } \\
\text { scale) }\end{array}$ \\
\hline $\begin{array}{l}\text { Potential coffee cultivation visit } \\
\text { perception3 }(C C P 3)\end{array}$ & $\begin{array}{l}\text { Coffee and coffee cultivation would add emotions and value to my trip in } \\
\text { a coffee-producing country ( } 1-5 \text { Likert scale) }\end{array}$ \\
\hline $\begin{array}{l}\text { Potential coffee cultivation visit } \\
\text { perception4 }(C C P 4)\end{array}$ & The livelihood of coffee farmers would impress me a lot (1-5 Likert scale) \\
\hline $\begin{array}{l}\text { Potential coffee cultivation visit } \\
\text { perception5 (CCP5) }\end{array}$ & $\begin{array}{l}\text { The discovery of coffee cultivation and tradition would push me to deepen } \\
\text { my knowledge over coffee ( } 1-5 \text { Likert scale) }\end{array}$ \\
\hline $\begin{array}{l}\text { Potential coffee cultivation visit } \\
\text { perception6 }(C C P 6)\end{array}$ & $\begin{array}{l}\text { The discovery of coffee cultivation and tradition would push me to } \\
\text { increase my coffee consumption ( } 1-5 \text { Likert scale) }\end{array}$ \\
\hline
\end{tabular}




\begin{tabular}{|c|c|}
\hline $\begin{array}{l}\text { Potential coffee cultivation visit } \\
\text { perception7 }(C C P 7)\end{array}$ & $\begin{array}{l}\text { I would be happy to visit a coffee cultivation if I would go in a coffee- } \\
\text { producing country (1-5 Likert scale) }\end{array}$ \\
\hline $\begin{array}{l}\text { Potential coffee cultivation visit } \\
\text { perception8 }(C C P 8)\end{array}$ & $\begin{array}{l}\text { I would enjoy coffee cultivation visits if I would go in a coffee-producing } \\
\text { country (1-5 Likert scale) }\end{array}$ \\
\hline $\begin{array}{l}\text { Potential coffee cultivation visit } \\
\text { perception } 9(C C P 9)\end{array}$ & $\begin{array}{l}\text { I feel that these countries could be somehow dangerous and/or risky } \\
(1-5 \text { Likert scale) }\end{array}$ \\
\hline $\begin{array}{l}\text { Potential coffee cultivation visit } \\
\text { interest }\end{array}$ & $\begin{array}{l}\text { If you have never visited the above-mentioned countries, are you planning } \\
\text { to go there in order to learn more over coffee, its cultivation, its history, } \\
\text { and its traditions? } \\
\text { - I am not interested in those countries } \\
\text { - I am not interested in coffee or coffee cultivations } \\
\text { - I would like to visit those countries but not because of coffee or its } \\
\text { cultivation } \\
\text { - I have never thought about that before, but it can be a good chance to } \\
\text { learn more } \\
\text { - Yes, I am planning to go to those countries in which coffee is } \\
\text { cultivated to enrich my general knowledge } \\
\text { - Yes, I am already planning such a travel because of my job } \\
\text { Yes, I am planning a travel like this because I am interested in coffee } \\
\text { and I would like to build my future job on coffee }\end{array}$ \\
\hline
\end{tabular}

Table 2 shows the descriptive statistics, which helps $u s$ to explain the key sample features. of the sample. The sample is balanced between male (53\%) and female (47\%) participants, and between young and old people even though the average age is low (27 years old). The average number of travels in coffeeproducing countries is 0.95 ; thus, many people have never travelled to those countries. Most of the participants consumed between 5 and 20 cups of coffees per day, and many hey neverwere not aware knew that there were coffee cultivation visits in the mentioned countries. Only a few of them had have ddone a coffee cultivation visit, thus highlighting the fact that this type of agricultural kind of tourism is stilleurrently at in its infancy. Regarding the coffee visit experience perception, the average values of all the 9 items range between 2 and 3. The most valued items are CCP2 (The coffee history and its traditions are very interesting for me), CCP7 (I would be happy to visit a coffee cultivation if I would go in a coffee-producing country) and CCP8 (I would enjoy coffee cultivation visits if I would go in a coffee-producing country).

Table 2. Descriptive statistics

\begin{tabular}{|c|c|c|c|c|}
\hline & Min & Max & Mean & Standard dev. \\
\hline Gender & 0 & 1 & 0.47 & 0.500 \\
\hline Age & 16 & 78 & 27.07 & 8.244 \\
\hline Travels & 0 & 19 & 0.95 & 2.293 \\
\hline Number of coffee & 0 & 4 & 2.17 & 1.225 \\
\hline Did you know coffee cultivation? & 0 & 1 & 0.26 & 0.438 \\
\hline Coffee cultivation visit & 0 & 1 & 0.07 & 0.260 \\
\hline Did you enjoy? & 0 & 1 & 0.09 & 0.292 \\
\hline CCP1 & 1 & 5 & 2.78 & 1.373 \\
\hline
\end{tabular}




\begin{tabular}{|l|l|l|l|l|}
\hline CCP2 & 1 & 5 & 2.81 & 1.349 \\
\hline CCP3 & 1 & 5 & 2.75 & 1.392 \\
\hline CCP4 & 1 & 5 & 2.64 & 1.298 \\
\hline CCP5 & 1 & 5 & 2.74 & 1.353 \\
\hline CCP6 & 1 & 5 & 2.13 & 1.211 \\
\hline CCP7 & 1 & 5 & 2.84 & 1.405 \\
\hline CCP8 & 1 & 5 & 2.82 & 1.375 \\
\hline CCP9 & 1 & 5 & 2.25 & 1.178 \\
\hline
\end{tabular}

These preliminary findings suggest that the perception of coffee visits/tourism could be is very-much appreciated by tourists and that therefore this type of tourism has offers great growth $s$ a potential for th.

\section{Findings}

This section presents the findings of the quantitative study, aimed at exploring the antecedents of perceptions, potentiality, attitudes and behavior of tourists, particularly with regard to coffee tourism and coffee cultivation visits. Table 3 shows the correlation matrix. This preliminary analysis indicates that gender, age, and number of travels in the mentioned countries are not significantly correlated with the items of CCP. In contrast, coffee consumption itself seems to impact several variables of CCP.

Table 3. Correlation matrix

\begin{tabular}{|c|c|c|c|c|c|c|c|c|c|c|c|c|c|}
\hline & Gender & Age & $\begin{array}{l}\text { Number } \\
\text { of } \\
\text { coffee }\end{array}$ & Travels & CCP1 & CCP2 & СCP3 & CCP4 & CCP5 & СCP6 & CCP7 & СCP8 & ССР9 \\
\hline Gender & 1 & 0.050 & 0.000 & 0.015 & 0.008 & 0.075 & 0.024 & 0.030 & 0.035 & -0.035 & -0.018 & 0.005 & 0.082 \\
\hline Age & 0.050 & 1 & -0.081 & $0.282^{* *}$ & 0.020 & 0.011 & 0.002 & 0.019 & 0.009 & 0.013 & -0.095 & -0.067 & 0.067 \\
\hline $\begin{array}{l}\text { Number } \\
\text { of } \\
\text { coffee }\end{array}$ & 0.000 & -0.081 & 1 & 0.055 & $0.174^{* *}$ & $0.179^{* * *}$ & $0.155^{* *}$ & $0.127^{*}$ & $0.164^{* *}$ & 0.092 & $0.125^{*}$ & 0.100 & 0.031 \\
\hline Travels & 0.015 & $0.282^{* *}$ & 0.055 & 1 & $0.134^{*}$ & 0.113 & 0.099 & 0.082 & 0.089 & 0.083 & 0.076 & 0.109 & 0.031 \\
\hline CCP1 & 0.008 & 0.020 & $0.174^{* * 4}$ & $0.134^{*}$ & 1 & $0.826^{* *}$ & $0.850^{* *}$ & $0.768^{* *}$ & $0.815^{* *}$ & $0.579^{* *}$ & $0.806^{* *}$ & $0.797^{* *}$ & $0.527^{* *}$ \\
\hline CCP2 & 0.075 & 0.011 & $0.179^{* *}$ & 0.113 & $0.826^{* *}$ & 1 & $0.767^{* *}$ & $0.719^{* *}$ & $0.789^{* *}$ & $0.572^{* *}$ & $0.734^{* *}$ & $0.733^{* *}$ & $0.526^{3 *}$ \\
\hline CCP3 & 0.024 & 0.002 & $0.155^{* *}$ & 0.099 & $0.850^{* *}$ & $0.767^{* *}$ & 1 & $0.828^{* *}$ & $0.847^{* *}$ & $0.650^{* *}$ & $0.814^{* *}$ & $0.811^{* *}$ & $0.515^{* *}$ \\
\hline СCP4 & 0.030 & 0.019 & $0.127^{*}$ & 0.082 & $0.768^{* *}$ & $0.719^{* * *}$ & $0.828^{* *}$ & 1 & $0.842^{* *}$ & $0.657^{* *}$ & $0.766^{* *}$ & $0.768^{* *}$ & $0.544^{* *}$ \\
\hline CCP5 & 0.035 & 0.009 & $0.164^{* *}$ & 0.089 & $0.815^{* *}$ & $0.789^{* *}$ & $0.847^{* *}$ & $0.842^{* *}$ & 1 & $0.644^{* *}$ & $0.780^{* *}$ & $0.776^{* *}$ & $0.546^{* *}$ \\
\hline СCP6 & -0.035 & 0.013 & 0.092 & 0.083 & $0.579^{* *}$ & $0.572^{* *}$ & $0.650^{* *}$ & $0.657^{* *}$ & $0.644^{* *}$ & 1 & $0.619^{* *}$ & $0.627^{* *}$ & $0.539^{* *}$ \\
\hline CCP7 & -0.018 & -0.095 & $0.125^{*}$ & 0.076 & $0.806^{* *}$ & $0.734^{* *}$ & $0.814^{* *}$ & $0.766^{* *}$ & $0.780^{* *}$ & $0.619^{* *}$ & 1 & $0.944^{* * *}$ & $0.552^{* *}$ \\
\hline CCP8 & 0.005 & -0.067 & 0.100 & 0.109 & $0.797^{* *}$ & $0.733^{* *}$ & $0.811^{* *}$ & $0.768^{* *}$ & $0.776^{* *}$ & $0.627^{* *}$ & $0.944^{* *}$ & 1 & $0.605^{* *}$ \\
\hline ССР9 & 0.082 & 0.067 & 0.031 & 0.031 & $0.527^{* *}$ & $0.526^{* *}$ & $0.515^{* *}$ & $0.544^{* *}$ & $0.546^{* *}$ & $0.539^{* *}$ & $0.552^{* *}$ & $0.605^{* *}$ & 1 \\
\hline
\end{tabular}


Despite these preliminary findings, it is necessary to conduct regressions to explore the relationships among variables. Gender, age, number of coffees, and travels are the independent variables, while CCP is the dependent variable. However, given that CCP is a multi-item variable, we performed a confirmatory factor analysis (CFA) by using principal component extraction with varimax rotation. First, we eliminated CCP9 as it concerns the perception of risk of the mentioned country. CFA generated one factor with the eight items CCP1, CCP2, CCP3, CCP4, CCP5, CCP6, CCP7 and CCP8, explaining a total of $78.968 \%$ of the observed variance. Consequently, we calculated a composite measure of the $\mathrm{CCP}$ by averaging the scores. Moreover, we assessed the correlation matrix through the KMO, and Bartlett's test resulted in an acceptable level of KMO statistic (0.924); additionally, a significant p-value was obtained for Bartlett's test of the construct. Cronbach's alpha was 0.962 .

In addition, a variance inflation factor (VIF) test was used to evaluate the effect of multicollinearity. VIFs for variables were smaller than 10 and ranged from 1.001 to 1.098 , below the threshold accepted in literature (Hair, 1995). This finding shows the suitability of the gathered data.

We then implemented ordinary least squares (OLS) models to explore relationships among variables, in line with previous studies (Krivonos, 2004; Jena, Chichaibelu, Stellmacher, \& Grote, 2012). Given the limited number of variables, only one model was performed with all the independent variables and the dependent variable. The OLS model partially confirms the preliminary analyses performed with the correlation matrix. Accordingly, while the effect of gender and age on CCP is not significant $(\beta=0.200)$ and $(\beta=-0.033)$, the effect of number of coffee and travels is positive and significant $\left(\beta=0.151^{*}\right)$ and $\left(\beta=0.112^{*}\right)$. Therefore, while the effect of travels on the items of the dependent variable is not significant in the correlation matrix, it does consider the whole construct of CCP in the regression model.

Table 4. OLS regression model

\begin{tabular}{|l|l|}
\hline Variable & Beta and T \\
\hline Gender & $0.200(0.332)$ \\
\hline Age & $-0.033(-0.0533)$ \\
\hline Number of coffee & $0.151(2.544)^{*}$ \\
\hline Travels & $0.112(1.814)^{*}$ \\
\hline R & 0.193 \\
\hline R-squared & 0.037 \\
\hline Adj. R-squared & 0.023 \\
\hline F & $2.669^{*}$ \\
\hline
\end{tabular}

Note: ${ }^{*} \mathrm{p}<0.05 ; * * \mathrm{p}<0.01 ; * * * \mathrm{p}<0.001$ 


\section{Discussion and conclusions}

\section{Discussion of findings}

This research was driven by growing interest in both the coffee industry and the experience economy that are leading to new tourist offerings related to food (Oh et al., 2007). In detail, our main purpose was to investigate whether and how tourism can be part of potential positive synergies in terms of coffee industry awareness, indigenous coffee farmers, and the challenges they face in the overall context of what is termed - country destination branding (Anholt, 2004; 2010).

The quantitative methodology involving a survey approach deployed to explore the antecedents of perceptions, potentiality, attitudes and behavior of tourists, particularly with regard to coffee tourism and coffee cultivation visits, considering the opportunity to develop joint initiatives that benefit both local stakeholders and tourists' experience (Byrth et al., 2017; Spielmann et al., 2018). A regression model was implemented to test the impact of several independent variables (gender, age, number of coffee, travels in coffee-producing countries) on the dependent variable (CCP). Concerning RQ1, which asked 'Are coffee places and countries interesting as tourism destinations, for the territorial value cocreation?', our research findings suggest that consumers have a positive perception of coffee cultivation visit (2.69 out of 5 if we consider the whole construct $\mathrm{CCP}$ ). Moreover, this perception is related to coffee consumption (the higher the number of coffees consumed during a day, the higher the perception of potential coffee cultivation visits as our findings indicate). This suggests that demand and awareness of coffee production and consumption increase the willingness to know more about coffee history, thus transforming coffee demand potentially into a holistic experience that goes beyond the mere consumption of coffee itself (Byrd, 2017; Gibbs and Holloway, 2017; Spielmann et al., 2018) and that creates a joint interest's satisfaction, as stated by the stakeholder theory for tourism services (Freeman et al., 2010). It should be noted that results coming from potential tourists' personal opinions, through one open question at the end on the online questionnaire, highlighted the will to deepen knowledge about coffee farmers and their lives, and confirms the role of authenticity in tourism experience (Spielmann et al., 2018). The following quotes demonstrate respondents' reactions:

\footnotetext{
"I really would like to experience the real coffee taste!"

"I'm expect to experience the real life of coffee farmers!"

"I want to know more about an element which Ito introduce to my body every day!"

"This would be a new experience for all five senses!!!"
}

Regarding RQ2, which asked 'can travels in coffee-producing countries reflect an improved coffeerelated tourism and a beneficial destination image?', our data indicate that the higher the number of travels in coffee-producing countries, the higher is the perception of coffee cultivation visit. This because, visiting a country increases the awareness of the customer towards the local tradition, cultures 
and products. The research findings are in line with the recent literature, which suggests that consumers, in most cases, want the experience, rather than to gather things (Byrd, 2017; Gibbs and Holloway, 2017; Spielmann et al., 2018). Thus, if the equatorial countries wish to create value, they definitively must consider that the experience represents a growing demand. In this context, coffee agriculture tourism can be considered a part of the experience economy, in which people want to know more about a product that is consumed every day (Quan and Wang, 2003). This is translated into a willingness to explore in greater detail the history of authentic products in a visited country, thus confirming the importance of conviviality as one of the main drivers in the experience economy (Hosany et al., 2006), and authenticity, which was already discussed by Spielmann et al. (2018).

Nevertheless, we have to underline that, despite the above-mentioned interest, some respondents pointed out the lack of infrastructures and some issues concerning local tourism management:

"I really enjoyed the place, even though sometimes going around was not so easy."

"The lack of communication infrastructures negatively affected my trip."

"Despite the farmers' kindness, it was very clear their lack in knowledge on how to host people."

Furthermore, this research confirms and adds to the literature the link between food and tourism. Accordingly, food is seen as 'the extension of the ontological comfort of home' (Quan and Wang, 2003, p. 301), and it is viewed as a key element to enhance the development and the attraction potential of a certain territory (Hall et al., 2016). Food is a way through which it is possible to experience a place (Spielmann et al., 2018) and a mechanism that allows people to get in touch with local culture (Sims, 2009), rituals (Joliffe, 2003; Plummer et al., 2005; Joliffe, 2010), and heritage (Zhou, 2014). Thus, food has a beneficial role in turning a tourist from being passive to active (Bruyere et al., 2009; Leonidou et al., 2015), and this has a strong impact on the brand image of a territory, as suggested in the literature (Kivela and Crotts, 2006; Cheng et al., 2012; Tapachai and Waryszan, 2000). Furthermore, this beneficial role enhances the destination image (Tapachai and Waryszak, 2000) by leveraging on five consumption values (Sheth et al., 1991): functional (tested people want to discover more about the roots of coffee), social (a strong will to understand local communities), emotional (this kind of experience is about involving all the human senses), epistemic (this is perceived as a possible brand new experience), and conditional (it offers another chance for promoting tourism choices).

The results confirm the above findings, as respondents who already had a touristic experience in coffee lands have augmented their destination image perception and this is additionally highlighted by some personal opinions provided in the qualitative comment section of the survey:

"My touristic experience has driven my opinion on how beautiful is this coffee land!"

"I didn't know about the beauty of this territory before my departure. Now I would like to return there asap!" 
"This country is not that risky as I was used to think before my touristic experience!"

\section{Implication for to theory and practice}

The research provides several theoretical implications. First, the study extends the finding of Tapachai and Waryszak (2000), suggesting that demand and awareness of coffee production and consumption increase the willingness of tourists to know more about coffee history, thus transforming coffee demand into a whole new experience that goes beyond the sole consumption of coffee.

Second, this research confirms and adds to the literature the link between food, tourism, and destination image in the specific context of coffee. In this regard, the positive reflex of rural tourism on local agricultural activities has been suggested in the context of the wine, beer, rice and tea industries (Plummer et al., 2005; Sims, 2009; Rogerso, 2011; Quadri-Felitti and Fiore, 2012; Sidali et al., 2013; Cheng et al., 2016; Vrontis et al., 2016). However, to the best of our knowledge, this aspect has never been considered in the context of coffee. Thus, this research has explored the link between coffee and tourism, indicating that coffee consumption and travel can boost the awareness of coffee cultivation visit perception and the overall coffee tourism experience, thus creating a shared value for all the stakeholders of the coffee industry. Furthermore, it also confirms that in the coffee-related tourism case, it is possible to discuss the stakeholder theory of Freeman (1984), as it is about a joint interest situation, or a 'congruency between perspectives' (Freeman et al., 2010: p. 150). Thus, this research indicates that coffee consumption and travels can boost the awareness toward coffee cultivation visit perception and the overall coffee tourism experience, creating a shared value for all the stakeholders of the coffee industry.

Managerially speaking, the paper offers the following implications and insights. First, long-term competitiveness of a destination brand image depends in large measure on how well prepared its future managers are. At this stage, farmers are, apparently, still not well trained to shift and modify their habits and, above all, their mentality in order to be ready to host people interested in coffee and coffee growing. It is possible to add that farmers are, in some cases, making efforts to enhance their situation, and this has also been possible because of the help provided by local NGOs and international coffee roasters. Farmers' willing to enter the tourism industry helps them even from the cultural perspective: economic benefits are often the most obvious, but the interaction between visitors and local communities can also nurture pride and help to maintain traditions.

Furthermore, the presence of infrastructure is fundamental to tourism, because, as a service, it needs appropriate places and effective transportation to reach the destination and to enjoy the destination as well. This represents one of the biggest problems in equatorial countries, as it has a certain kind of impact on potential tourists' perception of safety and travel appreciation. 


\section{Conclusions}

Coffee tourists' perceptions can be positively affected by the five above-mentioned consumption values (Tapachai and Waryszak, 2000) and it is reasonable to say that tourists themselves must be well informed and educated about coffee culture, its tradition and how it represents the heritage of its lands. Evidently, coffee visits and tourism perception are higher when tourist $\underline{s}$ know more about the coffee world. In keeping with this, we suggest that coffee roasters communication strategies, which are currently based on sustainability and how coffee cultivations are managed, can help focus potential coffee tourist attention. This leads to an opportunity for tour operators and local managers.

Finally, stakeholder recognition of tourism-based benefits is also an imperative for sustainable tourism (Bruyere et al., 2009) and its players. By understanding how different stakeholders perceive value of these benefits, governments, farmers, and private investors can effectively address relevant stakeholder needs.

\section{Limitations and future research}

This research should be considered in light of several limitations. First, the questionnaire was conducted in English, and therefore, only people who understand the language could have answered it. This means that a certain part of the population has been excluded from the research. Despite this limitation, it is reasonable to state that our research is directed towards active tourists, who are increasingly getting better at speaking English fluently. Second, our sample is heterogeneous in terms of countries, and therefore, some cultural features, not addressed herein this paper, could affect the findings. Future studies could attempt to gather more data and assess different sub-samples. In addition, future studies can try to explore whether the culture of travelers affect consumption and agriculturally related travel decisions

\section{References}

Aaker D.A. (1996), Building Strong Brands, The Free Press, New York.

Alonso, A. D. (2011). Opportunities and challenges in the development of micro-brewing and beer tourism: A preliminary study from Alabama. Tourism Planning and Development, 8(4), 415-431.

Anbalagan, K., and Lovelock, B. (2014). The potential for coffee tourism development in Rwanda-Neither black nor white. Tourism and Hospitality Research, 14(1-2), 81-96.

Anholt, S. (2004). Nation-brands and the value of provenance. Destination branding, 26-39.

Anholt, S. (2010). Definitions of place branding-Working towards a resolution.

Baloglu, S., and McCleary, K. W. (1999). A model of destination image formation. Annals of tourism research, 26(4), 868-897.

Beerli A., Martin J. D. and Quintana A. (2004), "A model of customer loyalty in the retail banking market", European Journal of Marketing, 38(1/2), 253-275.

Brenes, E. R., Montoya, D., and Ciravegna, L. (2014). Differentiation strategies in emerging markets: The case of Latin American agribusinesses. Journal of Business Research, 67(5), 847-855. 
Bresciani, S., Ferraris, A., Santoro, G., \& Nilsen, H. R. (2016). Wine sector: companies' performance and green economy as a means of societal marketing. Journal of Promotion Management, 22(2), 251-267.

Britton R. A. (1979), "The image of the Third World in tourism marketing", Annals of Tourism Research, 6(3), 318-329.

Bruyere, B. L., Beh, A. W., and Lelengula, G. (2009). Differences in perceptions of communication, tourism benefits, and management issues in a protected area of rural Kenya. Environmental management, 43(1), 49.

Byrd, E. T. (2007). Stakeholders in sustainable tourism development and their roles: applying stakeholder theory to sustainable tourism development. Tourism Review, 62(2), 6-13.

Candelo, E., Casalegno, C., Civera, C. and Mosca, F. (2018). "Turning Farmers into Business Partners through Value Co-Creation Projects. Insights from the Coffee Supply Chain”. Sustainability, 10(4), 1018.

Chang, P. L., and Chieng, M. H. (2006). Building consumer-brand relationship: A cross-cultural experiential view. Psychology and Marketing, 23(11), 927-959.

Chen, B., Qiu, Z., and Nakamura, K. (2016). Tourist preferences for agricultural landscapes: a case study of terraced paddy fields in Noto Peninsula, Japan. Journal of Mountain Science, 13(10), 1880-1892.

Cheng, S., Hu, J., Fox, D., and Zhang, Y. (2012). Tea tourism de velopment in Xinyang, China: Stakeholders' view. Tourism Management Perspectives, 2, 28-34.

Civera, C., Casalegno, C., Mosca, F., and Maple, P. (2018). Customers' judgments and misjudgments of corporate responsibility communication: A cross-country investigation of the effects on confidence and trust within the banking sector. Psychology and Marketing, 35(2), 138-149.

Civera, C., De Colle, S., \& Casalegno, C. (2019). Stakeholder engagement through empowerment: The case of coffee farmers. Business Ethics: A European Review, 28(2), 156-174.

Cohen E. (1993), "The heterogeneization of a tourist art”, Annals of Tourism Research, 20(1), 138-163.

Collins, C. M., Steg, L., and Koning, M. A. (2007). Customers' values, beliefs on sustainable corporate performance, and buying behavior. Psychology and Marketing, 24(6), 555-577.

Coudounaris, D. N., and Sthapit, E. (2017). Antecedents of memorable tourism experience related to behavioral intentions. Psychology and Marketing, 34(12), 1084-1093.

Crompton, J. L. (1979). Motivations for pleasure vacation. Annals of tourism research, 6(4), 408-424.

Crompton, J. L., and McKay, S. L. (1997). Motives of visitors attending festival events. Annals of tourism research, 24(2), 425-439.

Donaldson, T., and Preston, L. E. (1995), "The stakeholder theory of the corporation: Concepts, evidence, and implications", Academy of Management Review, Vol. 20 No. 1, pp. 65-91

Donert K. and Light D. (1996), "Capitalizing on location and heritage: Tourism and economic reorganization. Argentiere La Basse, High French Alps", in Harrison L. and Husbands W. (Eds.), Practicing responsible tourism, Brisbane: Wiley, 193-215.

Dougherty, M. L., and Green, G. P. (2011). "Local food tourism networks and word of mouth". Journal of Extension, 49(2), 1-8.

Echtner C. M. and Prasad P. (2003). "The context of third world tourism marketing", Annals of Tourism research, 30(3), 660-682.

Echtner C. M. and Ritchie, J. B. (1991), "The measurement of destination image: An empirical assessment", Journal of travel research, 31(4), 3-13.

Fakeye, P. C., and Crompton, J. L. (1991). Image differences between prospective, first-time, and repeat visitors to the Lower Rio Grande Valley. Journal of travel research, 30(2), 10-16.

Florek, M., \& Conejo, F. (2007). Export flagships in branding small developing countries: The cases of Costa Rica and Moldova. Place Branding and Public Diplomacy, 3(1), 53-72.

Franceschelli, M. V., Santoro, G., \& Candelo, E. (2018). Business model innovation for sustainability: a food startup case study. British Food Journal, 120(10), 2483-2494.

Franceschelli, M. V., Santoro, G., Giacosa, E., \& Quaglia, R. (2019). Assessing the determinants of performance in the recycling business: Evidence from the Italian context. Corporate Social Responsibility and Environmental Management. 
Freeman, R. E. (1984). Strategic management: A stakeholder perspective. Boston: Pitman, 13.

Freeman, R. E., Harrison, J. S., Wicks, A. C., Parmar, B. L., and De Colle, S. (2010). Stakeholder theory: The state of the art. Cambridge University Press.

Gauci A, Gerosa V and Mwalwanda C (2002) Tourism in Africa and the multilateral trading system: Challenges and opportu- nities. A background paper for the Economic Commission for Africa.

Gibbs, D., and Holloway, L. (2017). From experience economy to experience landscape: the example of UK trail centres. Area.

Gilmore J. H. and Pine B. J. (2002a), The experience is the marketing, BrownHerron Publishing.

Gilmore, J. H., and Pine, B. J. (2002). Customer experience places: the new offering frontier. Strategy and Leadership, 30(4), 4-11.

Greenwood, D. J. (1972). Tourism as an agent of change: A Spanish Basque case. Ethnology, 11(1), 80-91.

Grosspietsch M (2006) Perceived and projected images of Rwanda: Visitor and international tour operator perspectives. Tourism Management, 27: 225-234.

Hall C. M. (2010), Blending Coffee and Fair Trade Hospitality, in Joliffe L., Coffee Culture, Destinations and Tourism, pp.159-71. Bristol: Channel View.

Hall C., Michael R. and Sharples Liz "The consumption of experiences or the experience of consumption? An introduction to the tourism of taste" pp 1-24 in Hall, C. M., Sharples, L., Mitchell, R., Macionis, N., and Cambourne, B. (Eds.). (2003). Food tourism around the world. Routledge.

Hall, C. M., Sharples, L., Mitchell, R., Macionis, N., and Cambourne, B. (Eds.). (2004). Food tourism around the world. Routledge.

Hermans D. (1981), "The encounter of agriculture and tourism a Catalan case", Annals of Tourism Research, 8(3), 462-479.

Hosany, S., Ekinci, Y., and Uysal, M. (2006). Destination image and destination personality: An application of branding theories to tourism places. Journal of business research, 59(5), 638-642.

Hultman, M., Strandberg, C., Oghazi, P., and Mostaghel, R. (2017). The role of destination personality fit in destination branding: Antecedents and outcomes. Psychology and Marketing, 34(12), 1073-1083.

International Coffee Organization (ICO) (2018), Coffee Market Report, Dec 2018 www.ico.org

Jansen-Verbeke, M. (2009). The territoriality paradigm in cultural tourism. Tourism, 19(1-2), 25-31.

Jenkins, C. L. (2015). Tourism policy and planning for developing countries: some critical issues. Tourism Recreation Research, 40(2), 144-156.

Jiang, P., Jones, D. B., \& Javie, S. (2008). How third-party certification programs relate to consumer trust in online transactions: An exploratory study. Psychology \& Marketing, 25(9), 839-858.

Joliffe L. (2006), "Tea and Hospitality: More than a Cuppa", International Journal of Contemporary Hospitality Management 18:164-168.

Joliffe L. (2010), Coffee Culture, Destinations and Tourism, Bristol: Channel View.

Joliffe L. and Aslam M. (2009), "Tea Heritage Tourism: Evidence from Sri Lanka”, Journal of Heritage Tourism 4(4), 331-344.

Joliffe, L. (2003). The lure of tea: history, traditions and attractions IN Food Tourism Around the World, 2003, C. Michael Hall, Liz Sharples, Richard Mitchell, Niki Macionis and Brock Cambourne

Jones M. T. and Fleming, P. (2003), "Unpacking complexity through critical stakeholder analysis the case of globalization”, Business and society, 42(4), 430-454.

Kapferer J.N., (2004), The New Strategic Brand Management. Creating and sustaining brand equity long term, Kogane Page, London, UK

Kapferer, J. N. (1997). Strategic brand management: creating and sustaining brand equity long term, 2. Auflage, London.

Kim, Y. G., Eves, A., and Scarles, C. (2009). Building a model of local food consumption on trips and holidays: A grounded theory approach. International Journal of Hospitality Management, 28(3), 423-431. 
Kivela, J., and Crotts, J. C. (2006). Tourism and gastronomy: Gastronomy's influence on how tourists experience a destination. Journal of Hospitality and Tourism Research, 30(3), 354-377.

Kitchen, P.J. (2019) Marketing and Sustainability, Keynote address presented at The Italian Institute of Management (SIMA),20 June 2019.

Kotler, P., Bowen, J. T., Makens, J., \& Baloglu, S. (2017). Marketing for hospitality and tourism, Pearson, Essex

Lacher RG and Nepal SK (2010) From Leakages to Linkages:Local-Level Strategies for Capturing Tourism Revenue in Northern Thailand. Tourism Geographies 12(1): 77-99.

Lee, I., and Arcodia, C. (2011). The role of regional food festivals for destination branding. International Journal of Tourism Research, 13(4), 355-367.

Leonidou, L. C., Coudounaris, D. N., Kvasova, O., and Christodoulides, P. (2015). Drivers and outcomes of green tourist attitudes and behavior: sociodemographic moderating effects. Psychology and Marketing, 32(6), 635-650.

Mak, A. H., Lumbers, M., Eves, A., and Chang, R. C. (2012). Factors influencing tourist food consumption. International Journal of Hospitality Management, 31(3), 928-936.

Mason, M. C., and Paggiaro, A. (2009). Celebrating local products: the role of food events. Journal of Foodservice Business Research, 12(4), 364-383.

Meyer D. (2007), "Pro-poor tourism: From leakages to linkages. A conceptual framework for creating linkages between the accommodation sector and 'poor' neighbouring communities". Current issues in tourism, 10(6), 558583.

Midtgard, M. R. (2003). Authenticity-tourist experiences in the Norwegian periphery. New directions in rural tourism, 102-114

Morgan, N., Pritchard, A., and Pride, R. (2011). Destination brands: Managing place reputation. London: Routledge.

$\underline{\mathrm{N}}$

Oh, H., Fiore, A. M., and Jeoung, M. (2007). Measuring experience economy concepts: Tourism applications. Journal of travel research, 46(2), 119-132.

Oosterveer, P. (2006). Globalization and sustainable consumption of shrimp: consumers and governance in the global space of flows. International Journal of Consumer Studies, 30(5), 465-476.

Petchers, S., and Harris, S. (2008). The roots of the coffee crisis. Confronting the Coffee Crisis: Fair Trade, Sustainable Livelihoods and Ecosystems in Mexico and Central America. MIT Press, Cambridge, MA.

Phipps, M., Ozanne, L. K., Luchs, M. G., Subrahmanyan, S., Kapitan, S., Catlin, J. R., ... and Weaver, T. (2013). Understanding the inherent complexity of sustainable consumption: A social cognitive framework. Journal of Business Research, 66(8), 1227-1234.

Pine, B. J., Pine, J., and Gilmore, J. H. (1999). The experience economy: work is theatre and every business a stage. Harvard Business Press.

Plummer, R., Telfer, D., Hashimoto, A., and Summers, R. (2005). Beer tourism in Canada along the WaterlooWellington ale trail. Tourism Management, 26(3), 447-458.

Quadri-Felitti, D., and Fiore, A. M. (2012). Experience economy constructs as a framework for understanding wine tourism. Journal of Vacation Marketing, 18(1), 3-15.

Quan, S., and Wang, N. (2004). Towards a structural model of the tourist experience: An illustration from food experiences in tourism. Tourism management, 25(3), 297-305.

Richards, G. (2002). Gastronomy: An essential ingredient in tourism production and consumption? In A.-M. Hjalager and G. Richards (Eds.), Tourism and gastronomy (pp. 3-20). London: Routledge

Ritchie, J. B., and Crouch, G. I. (2003). The competitive destination: A sustainable tourism perspective. Cabi.

Rogerso, C. M. (2012). Strengthening agriculture-tourism linkages in the developing World: Opportunities, barriers and current initiatives. African Journal of Agricultural Research, 7(4), 616-623.

Rueegg M. (2009), "The impact of tourism on rural poverty through supply chain linkages to local food producers in the Bolivian Altiplano", Unpublished MSc (Development Studies) dissertation, London School of Economics and Political Science, 9. 
Santoro, G., Ferraris, A., \& Vrontis, D. (2018). Open social innovation: towards a refined definition looking to actors and processes. Sinergie, 105(Jan-Apr).

Sheth, J. N., Newman, B. I., and Gross, B. L. (1991). Why we buy what we buy: A theory of consumption values. Journal of business research, 22(2), 159-170.

Sidali, K. L., Kastenholz, E., and Bianchi, R. (2015). Food tourism, niche markets and products in rural tourism: Combining the intimacy model and the experience economy as a rural development strategy. Journal of Sustainable Tourism, 23(8-9), 1179-1197.

Sims, R. (2009). Food, place and authenticity: local food and the sustainable tourism experience. Journal of sustainable tourism, 17(3), 321-336

Spielmann, N., Babin, B. J., and Manthiou, A. (2018). Places as authentic consumption contexts. Psychology and Marketing, 35(9), 652-665.

Sun Y, Yin J, Cao H, Li C, Kang L, Ge F (2011) Elevated CO2 influences nematode-induced defense responses of tomato genotypes differing in the JA pathway. PLoS ONE 6(5): e19751

Tapachai, N., and Waryszak, R. (2000). An examination of the role of beneficial image in tourist destination selection. Journal of travel research, 39(1), 37-44.

Toledo, V. M., \& Moguel, P. (2012). Coffee and sustainability: the multiple values of traditional shaded coffee. Journal of Sustainable Agriculture, 36(3), 353-377.

Torres R. M. and Momsen, J. H. (Eds.). (2011), Tourism and agriculture: new geographies of consumption, production and rural restructuring, Taylor and Francis.

Torres, R. (2003). Linkages between tourism and agriculture in Mexico. Annals of tourism research, 30(3), 546566.

Torres, R., and Momsen, J. H. (2004). Challenges and potential for linking tourism and agriculture to achieve propoor tourism objectives. Progress in Development Studies, 4(4), 294-318

Um, S., and Crompton, J. L. (1992). The roles of perceived inhibitors and facilitators in pleasure travel destination decisions. Journal of travel research, 30(3), 18-25.

Vorley, B and Proctor, F. 2008. Modern Retail Food Industry in Southeast Asia. In Changing Agrifood Markets in Southeast Asia: Impact on Small-Scale Producers. Edited by Larry Digal, Felicity Proctor and Bill Vorley. SEAMEO SEARCA. Phillipine.

Vrontis, D., Bresciani, S., \& Giacosa, E. (2016). Tradition and innovation in Italian wine family businesses. British Food Journal, 118(8), 1883-1897.

Watson, K., and Achinelli, M. L. (2008). Context and contingency: the coffee crisis for conventional small-scale coffee farmers in Brazil. Geographical Journal, 174(3), 223-234.

Zhang, J., \& Mao, E. (2008). Understanding the acceptance of mobile SMS advertising among young Chinese consumers. Psychology \& Marketing, 25(8), 787-805.

Zhou, L. (2014). Online rural destination images: Tourism and rurality. Journal of Destination Marketing and Management, 3(4), 227-240. 